\title{
Privacy and Confidentiality in Exchange of Information Procedures: Some Uncertainties, Many Issues, but Few Solutions
}

\author{
Filip Debelva* \& Irma Mosquera**
}

\begin{abstract}
The overall aim of this article is to analyse the taxpayers' rights to confidentiality and privacy in exchange of information including the new global standard of automatic exchange of information. Section 2 will analyse the state of the art regarding the right to privacy and confidentiality in the OECD bilateral and multilateral instruments, in the Human Right Conventions and in case law by the European Court of Human Rights and the European Court of Justice. This section will also analyse the application of the right to privacy and confidentiality in practice mainly by identifying the problems of confidentiality and privacy arising in the disclosure of information, the exchange of trade secrets and the leak of information to the press and third parties. Subsequently, the authors explore the possibility to introduce a multilateral instrument to remedy these shortcomings.
\end{abstract}

\section{INTRODUCTION}

Exchange of information (EOI) is a hot topic. From the side of tax authorities, the increasing flows of information between countries undoubtedly provides advantages in terms of increased compliance and increased revenue. As several commentators have already pointed out, the increased availability of information also presents some challenges with regard to the protection of the taxpayer's rights. ${ }^{1}$ Most doctrine in this respect focus on the right to a fair trial and the lack of so-called 'participation rights' for the taxpayer involved. This paper aims to focus on the right to privacy and confidentiality, two rights which have according to the authors not yet gained sufficient attention in this debate.

In Section 2, the state of the art regarding the right to privacy and confidentiality, as applied to EOI procedures is discussed. Attention will be given to both theoretical considerations as well as some applications of the rights in practice. It will be concluded that there are currently not sufficient safeguards for the taxpayer. In Section 3, the authors explore the possibilities to introduce a new multilateral instrument to remedy these shortcomings.

\section{State of The ART}

\section{I Privacy vs Confidentiality}

\section{I.I Definition}

This article discusses both the right to privacy and the right to confidentiality, the importance of which have been

\section{Notes}

Ph.D Fellow, KU Leuven, Belgium. The author can be contacted at email: filip.debelva@kuleuven.be. A previous draft this article was presented at the Fourth Annual Tax Symposium, organized by the University of Washington School of Law. The authors would like to thank the participants of the aforementioned conference and the anonymous peer reviewers of this article for their insightful comments and suggestions.

** Senior Research Associate at the International Bureau of Fiscal Documentation, Tax Adviser Hamelink \& Van den Tooren, the Netherlands. The author can be contacted at email: irma.mosquera@gmail.com.

A previous draft of this article was presented at the Fourth Annual Tax Symposium, organized by the University of Washington School of Law. The authors would like to thank the participants of the aforementioned conference and the anonymous peer reviewers of this article for their insightful comments and suggestions.

D. Bentley, Taxpayers' Rights. Theory, Origin and Implementation (The Netherlands: Kluwer Law International 2007); The Confédération Fiscale Européenne at 50 Years (Servaas Van Thiel ed., Belgium: Confédération Fiscale Européenne 2009); A. Cockfield, Protecting Taxpayer Privacy Rights Under Enhanced Cross-Border Tax Information Exchange: Toward a Multilateral Taxpayer Bill of Rights, 42 Univ. Brit. Col. L. Rev. 2 (2010); X. Oberson, General Report, in Exchange of Information and Cross-Border Cooperation Between Tax Authorities vol. 98b, 19-20 (IFA Cahiers, Online Books IBFD 2013); IFA Report. P. Pistone \& P. Baker, General Report. The Practical Protection of Taxpayers' Fundamental Rights, International Fiscal Association (IFA), Cahiers de droit fiscal international, vol. 100B (Amsterdam, the Netherlands: International Bureau of Fiscal Documentation 2015); A.P. Dourado, Exchange of Information and Validity of Global Standards in Tax Law: Abstractionism and Expressionism or Where the Truth Lies, European University Institute, Working Paper RSCAS 2013/11 (2013); I. Burgers, Taxpayers' Rights in Het Gedrang?, Nederlands Tijdschrift voor Fiscaal Recht 2015/2867 (2015); I.J. Mosquera Valderrama, Legitimacy and the Making of International Tax Law: The Challenges of Multilateralism, 7 World Tax J. 3 (2015), Journals IBFD; N. Diepvens \& F. Debelva, The Evolution of the Exchange of Information in Direct Tax Matters: The Taxpayer's Rights under Pressure, 24(4) EC Tax Rev. 210-219 (2015); I.J. Mosquera Valderrama. Legitimidady protección de derechos en el intercambio de información: la perspectiva del contribuyente. Estudios de Derecho Tributario, Derecho Aduanero y Comercio Exterior 509-534 (Feb. 2016), F. Debelva \& N. Diepvens, Exchange of Information. An Analysis of the Scope of Article 26 OECD Model and Its Requirements: In Search for an Efficient but Balanced Procedure, $44(4)$ Intertax 298-306 (2016); I.J. Mosquera Valderrama, The Rights of Multinationals in the Global Transparency Framework: McCarthyism?, 18 Derivs. \& Fin. Instrums. 1 (2016), Journals IBFD. 
underestimated in tax literature until very recently. ${ }^{2}$ This gap in literature can in our opinion at least partly be explained by the confusion surrounding these concepts. Privacy is sometimes defined as the right to keep one's affairs secret, ${ }^{3}$ while the right to confidentiality means that information disclosed to a person or entity should not be disclosed to an unrelated third party whether intentionally or by accident. In tax information exchange (TIE), the right to confidentiality means that the taxpayer should have confidence that the information exchanged is used and disclosed only in accordance with the agreement on the basis of which it is exchanged'.

However, even a very straightforward example of exchange of tax information reveals that the relationships of privacy and confidentiality are more complex when a concrete situation is being evaluated. For example: state A wants to obtain information regarding alleged unreported bank accounts held by one of its residents with a financial institution in state B. The competent authorities of state A send a request for information to the competent authorities of state $\mathrm{B}$ on the basis of a double taxation convention (Article 26 OECDMC). It is clear that this process prima facie interferes with the taxpayer's right to privacy. In addition, several relationships can be identified. First, if state B sends a request to a financial institution in state B to obtain information regarding that that taxpayer, the financial institution has to breach its relationship of confidentiality vis-àvis the taxpayer (which usually takes the form of banking privilege). The taxpayer has trusted the financial institution with its personal dealings and assumes that its information is not shared with unrelated third parties. Second, after information has been obtained by the state B competent authorities, the financial institution trusts those authorities not to disclose that information to unauthorized persons or make it publicly available. Third, after the information has been transmitted from the state $\mathrm{B}$ tax authorities, to the state A tax authorities, the state $\mathrm{A}$ authorities are under an obligation both vis-à-vis the state $\mathrm{B}$ authorities and the taxpayer himself to keep the information confidential on the basis of the provisions of the double tax convention (DTC).

The precise content of these rights is also unclear. For example, the right to privacy has physical and spatial aspects. ${ }^{5}$ At the same time, others have submitted that a more modern notion of the right to privacy should also entail control over one's personal data streams, ${ }^{6}$ which adds a connotation making the right to privacy more suited for evaluating the transfer and exchange of taxrelated information. Elsewhere it was also submitted that the definition of privacy is context-dependent, meaning that the application of this right can lead to different results depending on the factual constellation to which it is applied. ${ }^{7}$ This makes it clear that privacy, data protection and confidentiality should not be viewed as separate, but are actually intertwined. At the same time, both privacy and confidentiality are sometimes mentioned as forming part of a wider right to data protection.

\section{I.2 Increasing Information Exchange also Increases Relevance of Privacy and Confidentiality}

\section{I.2.I General}

The possibilities and instruments for countries to collect and exchange information have been rapidly increasing. In the past, tax assessments predominantly relied upon information which was provided to the tax authorities by the taxpayer himself through his or her tax declaration. The global quest for more transparency has not only lead to an increasing EOI, but the types of information which are being shared (e.g. financial information, rulings and APA's,) has also increased. Furthermore, more information is also becoming 'fiscally relevant' due to the increasing use of taxation to realize other than mere budget-related goals. Additional information has to be reported in case taxpayers wish to call upon specific tax exemptions. For example, certain tax exemptions aim to achieve a better protection of the environment. This has led to the introduction in several countries of tax incentives for environmental friendly cars. In practice, this usually means that the taxpayer demonstrates that his or her car complies with the requirements as set out by the law. This boils

\section{Notes}

See e.g. M. Somare \& V. Wöhrer, Automatic Exchange of Financial Information Under the Directive on Administrative Cooperation in the Light of the Global Movement Towards Transparency, 43(12) Intertax 804-814 (2015); M. Schaper, Data Protection Rights and Tax Information Exchange in the European Union: An Uneasy Combination, 23(3) Maastricht J. Eur. Comp. L. 514-530 (2016).

Secret means also confidentiality since these terms are synonymous and interchangeable. See also in this regard. Para. 94 Commentary to Art. 8 of the TIEA Model.

OECD, Keeping It Safe: The OECD Guide on the Protection of Confidentiality of Information Exchanged for Tax Purposes 5 (OECD Publishing 2012).

The latter is for example of relevance for tax audits. For instance, regarding the access by tax authorities to the documents of the taxpayer available in the business offices of the taxpayer and his personal home. This approach to the right to privacy may also affect the right to professional secrecy. The right to professional secrecy entails the right to have one's personal and business information which was disclosed to the acting professional (e.g. auditor, accountant, tax advisor, lawyer, notaries, trustee, etc.) as secret. One example where the physical and spatial aspects may affect the professional secrecy is for instance in Brazil, where the attorney-client privilege applies not only to the communication, but also to the working documents and working premises. See I. Mosquera Valderrama et al., The Rule of Law and the Effective Protection of Taxpayers' Rights in Developing Countries (Forthcoming 2017). This article forms part of the comparative research conducted in terms of the DeSTat Research Project (Sustainable Tax Governance in Developing Countries through Global Tax Transparency). Funding for the project is provided by the Research Council in Norway. Further information about the project http://www.jus.uio.no/english/research/projects/global-transparency/ (accessed March 2017)

6 See for an application: C.C. Aggarwal \& P.S. Yu, An Introduction to Privacy-Preserving Data Mining, in Privacy-Preserving Data Mining 7 (C.C. Aggarwal \& P.S. Yup eds, Springer 2008)

On this subject H. Nissembaum, Privacy in Context (Stanford University Press 2010). 
down to the taxpayer providing information (possibly through an attestation) such as the brand of his car, the year of manufacture, and the year of purchase. Information which was in the past considered to be irrelevant for tax purposes is becoming increasingly relevant to achieve regulatory goals of the tax system.

In the examples mentioned in section 2.1.1. above, the tax administration is still relying on information which is provided to it by the taxpayer himself. However, in several countries, mechanisms are in place that allow the sharing of information from other government agencies and administrations with the tax authorities. This sharing of information does not only take place between tax administrations (e.g. information collected for sales tax or VAT purposes is transmitted to the direct tax authorities), but other non-tax entities are usually under an obligation by virtue of domestic law to provide information to the tax authorities. In this case, the non-tax entity will need to provide the necessary information to the tax authorities. For example, in order to correctly assess a taxpayer's immovable goods for the application of a wealth tax, the tax authorities can request information from a land registry agency. ${ }^{8}$

In addition, the tax administration is in most countries dependent upon reporting obligations by third parties in order to make the tax assessment system more efficient and reliable. For example, employers and financial institutions are usually under an obligation to report income obtained by the taxpayer directly to the tax authorities. This system can of course be of aid to the taxpayer due to less cumbersome reporting obligations on his side (e.g. such information can be used to prepopulate tax returns), but at the same time, using this method inherently carries the risk that incorrect information is being reported by these third parties, which could adversely affect the taxpayer.

After the information, has been collected by the tax administration, it can also be used for non-tax purposes. For example, in some states the tax administration is under a legal obligation to report possible violations of law to other authorities (e.g. the public prosecutor or economic or social inspections which overview the compliance with economic or labour law regulations).

Recent issues include the use of 'big data' which is used for tackling tax fraud. This technique could result in 'data profiling'. As rightly stated by Cockfield, "the use of huge amounts of data can have an actual and potential impact on the right to confidentiality and privacy of the taxpayer in case that the taxpayer's personal and business information may be used to construct a detailed profile of an individual's identity, including her religious beliefs, political alliances, and personal behavior'. ${ }^{9}$ The data which is necessary for such profiling can be collected by cross-referencing tax databases "with other information such as vehicle registrations, credit card information, or information held by financial intermediaries, to find individuals whose spending/investment patterns and tax contributions do not match up'. ${ }^{10}$ Therefore, and in line with the current European development on data protection, we argue that in order to protect the use of big data, the requirements of transparency and accountability, as stated by the European Data Protection Supervisor should also be applicable to tax administration like other government agencies when dealing with personal and business data of the taxpayer. ${ }^{11}$

It is clear that these recent developments bring up several questions for the taxpayer: who has access to my personal information? To which entities or states is this information being transmitted? How long is my information retained there? How can I correct mistakes? There is indeed a need for a coherent framework of protection in view of the goal of achieving more legal certainty for the taxpayer, especially given the international developments in this respect (see below).

\subsubsection{International Developments}

Control over personal data streams is even more important on the international level, where information is being transmitted across states, thus allowing more persons to handle the information and therefore potentially increasing the risk of security breaches. Information which has

\section{Notes}

8 Another case where the use of the information is not motivated by a budget-related goal is the use of information to tackle corruption or money laundering. To achieve these objectives, several countries have implemented domestic (tax) information collecting and sharing mechanisms. The tax administration is no longer predominantly depending on information which is being submitted by the taxpayer himself, but other non-tax entities such as the agencies to tackle corruption and money laundering and the financial institutions are feeding information for tax purposes. See s. 2.2.1 below.

9 For Cockfield 'tax information may reveal, among other things, information about income, spending and savings, employment status, personal belongings, disability status, associations and club memberships, donations to charities, mortgage costs, child support and alimony, and the amount and size of gifts to family members and others'. A Cockfield. Protecting taxpayer privacy rights under enhanced cross-border tax information exchange: Toward a multilateral taxpayer bill of rights. 2 U.B.C. Law Review 42 (2010) ., at 437-438.

10 In Opinion $7 / 2015$ the European Data Protection Supervisor stated that 'new business models exploiting new capabilities for the massive collection, instantaneous transmission, combination and reuse of personal information for unforeseen purposes have placed the principles of data protection under new strains, which calls for thorough consideration how they are applied'. Therefore, as rightly stated by the European Data Protection Supervisor, more effective data protection is required to counterbalance the challenges and risks resulting from the use of big data. Opinion 7/2015. Meeting the challenges of big data: A call for transparency, user control, data protection by design and accountability. Opinion of the European Data Protection Supervisor dated 19 Nov. 2015, at 4

11 In order to protect the use of big data, the European Data Protection Supervisor stated that responsible and sustainable development of big data must rely on transparency of organizations about how they process personal data, control by the user on how their data is being used, better design of user friendly data protection into their product and services, and more accountability of these organizations. Ibid., at 4 and 18 . 
been mistakenly submitted by the taxpayer to a national agency risks being shared not only with its own tax authorities, but also with other states. The combination of several concurring initiatives from the OECD, EU and US lead to an exponential number of instruments to exchange information. Countries and governments have agreed that EOI is necessary to prevent tax evasion and to tackle tax avoidance including aggressive tax planning. ${ }^{12}$ Therefore, in addition to bilateral instruments such as DTCs and Tax Information Exchange Agreements (TIEAs); several multilateral instruments to exchange information have been introduced by the OECD, EU and US. Below we provide a non-exhaustive overview.

Generally, the abovementioned information which has been gathered by the tax authorities can also be shared with other states, either upon request (as soon as it is 'foreseeably relevant' under the applicable instruments) or even automatically. One example is for instance the 2010 Foreign Account Tax Compliance Act (FATCA) that requires financial institutions around the world to provide information on the banking accounts of US citizens. This information is sent by the financial institution to the national tax administration which will be directly forwarded to the Internal Revenue Services 'IRS' (US Tax Administration). This requirement has been implemented by means of the Intergovernmental Agreements (IGAs). ${ }^{13}$

At OECD level, several legal instruments have been published, such as the 1988 OECD-Council of Europe Multilateral Convention on Mutual Administrative Assistance in Tax Matters and its 2010 Protocol (MAC) ${ }^{14}$, the 2014 Common Reporting Standard (CRS), and the Multilateral Competent Authority Agreement for Automatic Exchange of Financial Account Information
(CRS MCAA). ${ }^{15}$ The automatic exchange of Financial Account Information introduced by the CRS and its MCAA followed the introduction of FATCA by the United States. Concerns have risen regarding the compatibility of the CRS with the right to privacy. ${ }^{16}$ Recently, it was called 'the greatest onslaught against family trust in nearly 500 years: not since Henry VIII and the Statute of Uses in 1536 have trusts and their beneficiaries faced so ferocious an attack' ${ }^{17}$

The OECD, following the political G20's mandate, ${ }^{18}$ also launched the Base Erosion and Profit Shifting (BEPS) Report and its Action $\operatorname{Plan}^{19}$ with fifteen Actions to tackle tax avoidance, harmful tax practices and aggressive tax planning. Among these actions, Action 5 deals with Harmful Tax Regime and introduces compulsory spontaneous exchange on rulings related to preferential regimes. Action 13 deals with transfer pricing documentation that provides for exchange of documentation such as master file, local file and country-by-country reports among countries. In order to obtain the information not only from the local affiliate under examination but also from the multinational group of companies, countries may use any of the EOI mechanisms including automatic exchange of information (AEOI). ${ }^{20}$ Actions 5 and 13 are two of the four minimum standards that countries participating in the BEPS Inclusive Framework will need to implement in their domestic tax system. ${ }^{21}$ Therefore, these countries will be required to exchange transfer pricing documentation including country by country reporting.

This development has resulted in countries introducing domestic legislation to implement Action 13. The OECD has introduced an implementation package ${ }^{22}$ including

\section{Notes}

12 The standard of transparency including exchange of information on request was endorsed in the G20 Summits in Washington, London and Pittsburgh, and G8 Summits in L'Aquila and Lecce (Italy); Hokkaido (Japan). The G20 meeting of Sept. 2013 in Saint Petersburg endorsed the development of a new global tax standard i.e. automatic exchange of information. Tax Annex to the St. Petersburg G20 Leader's Declaration (Sept. 2013), para. 3.

13 At the time of writing (Mar. 2017), more than 110 countries have signed IGAs with the US.

14 At the time of writing (Mar. 2017), more than 100 countries have signed the MAC.

15 At the time of writing (Mar. 2017) more than 80 countries have signed the CRS MCAA.

16 These privacy-related concerns were undoubtedly raised by the fact that the CRS impose extensive reporting obligations (which includes anti-money laundering and know your client-procedures), whereby the financial institution can even be obliged to look through passive entities in order to reveal their true beneficiaries.

17 D. Dwyer, Privacy - Going, Going Gone? Be Afraid, Be Very Afraid, Offshore Inv. nr. 267, 16 (2016).

18 The BEPS and the Action Plan have been endorsed in the G20 meetings at Mexico (June 2012) and St Petersburg (Sept. 2013) respectively. G20 Leaders Declaration in St. Petersburg of 6 Sept. 2013. See in particular, para. 50 of the Declaration, where it has been stated that: 'In a context of severe fiscal consolidation and social hardship, in many countries ensuring that all taxpayers pay their fair share of taxes is more than ever a priority. Tax avoidance, harmful practices and aggressive tax planning have to be tackled'.

19 OECD, Addressing Base Erosion and Profit Shifting (OECD Publishing 2013) and OECD, Action Plan on Base Erosion and Profit Shifting (OECD Publishing 2013).

20 OECD, Guidance on Transfer Pricing Documentation and Country-by-Country Reporting, para. 15, OECD/G20 Base Erosion and Profit Shifting Project (Paris, OECD Publishing 2014).

21 In the Meeting in Kyoto, Japan (29 June-1 July 2016) the OECD presented an inclusive framework for the implementation of BEPS. This Inclusive Framework allows countries and jurisdictions outside the BEPS forty-four group to participate as BEPS Associates on the implementation of BEPS. The BEPS Project and its Inclusive Framework contains four minimum standards i.e. Action 5 dealing with Countering Harmful Tax Practices more effectively; Action 6 Preventing the granting of treaty benefits in inappropriate circumstances; Action 13 dealing with Transfer Pricing Documentation and Country by Country Reporting and Action 14 Making Dispute Resolutions more Effective. These four minimum standards should be implemented into the tax system of the countries participating in this framework. The other Actions $(1,2,3,4,7,8,9,10,11,12)$ comprise recommendations and best practices for countries to implement. At the time of writing (Mar. 2017) more than 90 countries are participating in the BEPS Inclusive Framework.

22 In order to facilitate the implementation of the country by country reporting standard, the OECD has provided an implementation package. According to the OECD, this package "consists of (i) model legislation which could be used by countries to require the ultimate parent entity of an MNE group to file the CbC Report in its jurisdiction of residence including backup filing requirements and (ii) three model Competent Authority Agreements that could be used to facilitate implementation of the exchange of 
the 2016 MCAA on the Exchange of Country by Country Reports (CbC MCAA) to facilitate the exchange of country by country reporting. ${ }^{23}$ However, despite these new instruments introducing even more options (and obligations) to exchange tax information, the safeguards for confidentiality and privacy have not been amended accordingly (see section 2.1.3. below). ${ }^{24}$

At EU level, in the field of Direct Taxation, the Council Directive 2011/16/EU as regards administrative cooperation in the field of taxation has been amended by extending the cooperation between tax authorities to automatic exchange of financial account information (Council Directive 2014/107/EU of 9 December 2014) and automatic exchange of cross-border tax rulings and advance pricing arrangements (Council Directive 2015/2376/EU of 8 December 2015). In 2016, the Council Directive on administrative cooperation has been also amended to introduce the mandatory automatic exchange of non-public country-by-country reporting (Council Directive 2016/ 881 of 25 May 2016) and to extend the access by tax authorities to anti-money-laundering information (Council Directive 2016/2258 of 6 December 2016).

In addition, recent proposals have been presented by the European Commission to amend the Accounting Directive and the 4th Anti-Money Laundering Directive. ${ }^{25}$ The proposed changes to the Accounting Directive includes the requirement of (public) country-by-country reporting for multinationals (EU and non-EU) with turnover of more than EUR $750 \mathrm{~m}$ and operating in Europe. ${ }^{26}$ The changes to the Fourth Anti-Money Laundering Directive include the full public access to beneficial ownership registers. This measure will affect companies and business related trusts. ${ }^{27}$

\subsubsection{Drawbacks of the New Global Standard}

It has been argued by both authors elsewhere ${ }^{28}$ that attention for the taxpayer's rights are more needed now due to the adoption of the new global standard of AEOI. There has been a shift from exchange upon request to AEOI. In AEOI, not only specific items of information relating to a single taxpayer (or a specific group of taxpayers), but a bulk of information will be exchanged Therefore, countries should take into account that due to the fast pace in which AEOI is going to take place, the result may be less control over the accuracy and use of the information by the receiving and supplying authorities. $^{29}$

Another situation that also raises concerns regarding the protection of the taxpayers' rights is the sharing of information. Unlike in the past, when only tax authorities could receive information, subject to a strict duty of confidentiality and sanctions in case of breach of the duty, ${ }^{30}$ nowadays, information can also be shared with other non-tax entities. These entities are for instance commissions or agencies aiming to investigate alleged corruption or which intend to tackle money laundering. Since the name and status of these agencies can be different in accordance to each country, it is not clear whether these entities will also have the strict duty of confidentiality and what could happen if such duty would be breached. ${ }^{31}$ The OECD Model and the MAC have made it possible for the tax administration of the supplying state to exchange information for tax purposes and nontax purposes (e.g. corruption, money laundering) with the Receiving State. ${ }^{32}$

\section{Notes}

CbC Reports'. These models are based on the: (1) Multilateral Convention on Administrative Assistance in Tax Matters, or (2) Bilateral tax conventions, or (3) Tax Information Exchange Agreements (TIEAs)

23 At the time of writing (Mar. 2017), more than 50 countries have signed the CbC MCAA

24 For instance, the MCAA based on the Multilateral Convention on Administrative Assistance in Tax Matters (MAC) in s. 5 dealing with Confidentiality, data safeguards and appropriate use states that 'All information exchanged is subject to the confidentiality rules and other safeguards provided for in the Convention, including the provisions limiting the use of the information exchanged'.

25 Respectively Directive 2013/34/EU of the European Parliament and of the Council of 26 June 2013 on the annual financial statements, consolidated financial statements and related reports of certain types of undertakings, amending Directive 2006/43/EC of the European Parliament and of the Council and repealing Council Directives 78/660/ EEC and 83/349/EEC Text with EEA relevance and Directive (EU) 2015/849 on preventing the use of the financial system for money laundering or terrorist financing (4th Anti-Money Laundering Directive) - seeks to protect credit and financial institutions against these risks.

26 Proposal for a Directive of the European Parliament and of the Council amending Directive 2013/34/EU as regards disclosure of income tax information by certain undertakings and branches. COM/2016/0198 final - 2016/0107 (COD).

27 Other trusts will be included in the national registers and will be available to parties who can show a legitimate interest. Proposal for a Directive of the European Parliamen and of the Council amending Directive (EU) 2015/849 on the prevention of the use of the financial system for the purposes of money laundering or terrorist financing and amending Directive 2009/101/EC. COM/2016/0450 final - 2016/0208 (COD). At the time of writing (Mar. 2017), these proposals to amend the above-mentioned Directives have not yet been adopted.

28 Mosquera Valderrama, Legitimacy and the Making of International Tax Law., supra n. 1, at 370; Diepvens \& Debelva, The Evolution of the Exchange of Information in Direct Tax Matters., supra n. 1 , at 215

29 Mosquera Valderrama, Ibid., at 370.

30 These sanctions can be for instance dismissal, fine, prison.

31 Examples are in Nigeria the Independent Corrupt Practices Commission and the Special Control Unit Against Money Laundering and in Colombia the Financial Intelligence Unit (a special administrative unit).

32 This provision has not been included in the text of Art. 26(2) of the UN Model. However, the UN Commentary to Art. 26 states the text that can be added by contracting states if they wish to broaden the purposes for which the information may be exchanged. The 2016 UN Manual for the Negotiation of Bilateral Tax Treaties states that 'if the two countries wish to allow the information to be used for a broader range of purposes (e.g. in money-laundering cases), they should specifically provide for this'. See also paras 13-13.3 of the Commentary on Art. 26 of the 2011 UN Model. The wording in the UN is identical to the wording of the OECD Model commentary. The wording included in the OECD Model is 'information received by a Contracting State may be used for other purposes when such information may be used for such purposes under the 
Several tax scholars have argued that taxpayer protection should be increased in this area. For instance, in 2014, the General Reporter for the European Association of Tax Law Professors stated that there is 'a tension between the legitimate rights of States to protect their tax base by collecting information of taxpayers as much as possible to guarantee taxation and the legitimate rights of taxpayers on privacy and to be protected against the almighty power of these States. ${ }^{33}$ Similarly, Pistone has also appealed for an increased taxpayer protection stating that '(s)tronger powers for tax authorities to cooperate in cross-border scenarios worldwide should march hand-in-hand with a stronger protection of taxpayers' basic rights. ${ }^{34}$

In our view, the protection of taxpayers' rights in the relationship between the taxpayer and the tax administration taking part in the EOI process needs to be addressed. Therefore, the questions that should be asked are: how will the OECD and countries protect the right to confidentiality and the right to privacy? What measures should be included to balance the power between the tax administration and the taxpayer? The protection of the taxpayer's right to confidentiality and privacy may help to ensure a better relationship between the taxpayer and the tax administration which should be based on trust, voluntary compliance and protection of taxpayer' rights. ${ }^{35}$ Furthermore, the protection of taxpayers' rights will enhance the legitimacy of the multilateral instruments to exchange information vis-à-vis the taxpayer. ${ }^{36}$

To summarize, in this area there have been recent developments which have led to an increasing collection and dissemination of information. A wider group of persons have access to tax-related information, and, as will be shown in the following sections, the protection which is offered to taxpayers is inadequate and has even diminished at the same time. We argue that current international (human rights) instruments impose an obligation upon states to improve the taxpayer's position from a privacy and confidentiality perspective. This will be elaborated upon in the following section.

\subsubsection{Sources}

Both of the analysed rights (privacy and confidentiality) can be found in provisions or instruments which provide a legal base for the EOI, either domestic or international instruments, or in autonomous instruments which are also applicable outside the area of EOI (e.g. human rights conventions). ${ }^{37}$

\section{I.3.I EOI Instruments}

The existing instruments which provide for procedures to exchange tax information on the international level contain inconsistent references to the right to privacy and confidentiality.

- The OECD and UN Treaty Models refer to the right to confidentiality. ${ }^{38}$ The commentaries to these models further refer to data protection and the right to privacy: if contracting states are required, according to their law, to observe data protection laws, these states can include provisions in their bilateral conventions concerning the protection of personal data exchange. The Commentaries also state that data protection concerns the rights and fundamental freedoms of an individual, and in particular, the right to privacy, with regard to automatic process of personal data. ${ }^{39}$ Conversely, the TIEA Model (and its 2015 Protocol) and Commentaries do not mention privacy or data protection, but only refer to the right to confidentiality. ${ }^{40}$

- The preamble to the MAC states that countries should carry out measures or supply information having regard to the necessity of protecting the confidentiality of information, and taking into account of international instruments for the protection of privacy and flows of personal data. ${ }^{41}$ Article 22(1) of the

\section{Notes}

laws of both States and the competent authority of the supplying State authorizes such use'. This wording is not found in the 2002 TIEA Model or its 2015 Protocol, which extends the scope of TIEAs to include automatic and spontaneous exchange of information.

33 G. Marino, General Reporter. New Exchange of Information versus Tax Solutions of Equivalent Effect, EATLP Annual Congress, Istanbul, 29-31 May 2014, 46 (Amsterdam, IBFD Publications 2015).

34 P. Pistone, Coordinating the Action of Regional and Global Players during the Shift from Bilateralism to Multilateralism in International Tax Law, 6(1) World Tax J. 4 (2014), Journals IBFD.

35 A tax system which is perceived as fair might also increase trust in the system as such and might consequently increase voluntary compliance. See E. Kirchler, E. Hoelzl \& I. Wahl, Enforced Versus Voluntary Tax Compliance: The 'Slippery Slope' Framework, 29 J. Econ. Psychol. 213 (2008). See also M.T. Soler Roch, Tax Administration versus Taxpayer A New Deal?, 4 World Tax J. (2012), Journals IBFD.

36 See s. 3.1.2. below. See also Mosquera Valderrama, Legitimacy and the Making of International Tax Law., supra n. 1.

37 Note that evidently specific EOI instruments will need to comply with (semi-) constitutional standards such as the rights contained within human rights instruments. However, the authors have chosen to discuss both types in order to give a more complete overview of applicable norms within this legal field.

38 OECD Model Art. 26(2) and UN Model Art. 26(2) refer to information to be treated as secret.

39 Para. 10 Commentary to para. 26(1) to OECD Model and para. 5.2. Commentary to Art. 26 UN Model.

40 Art. 82002 TIEA Model refer to information to be treated as confidential.

41 Preamble 2011 Convention and para. 1 Explanatory report to the Convention on Mutual Administrative Assistance in Tax Matters as Amended by the Protocol. OECD/ Council of Europe, France (2011), The Multilateral Convention on Mutual Administrative Assistance in Tax Matters: Amended by the 2010 Protocol, OECD Publishing. 
MAC deals with secrecy referring to confidentiality and protection of personal data. ${ }^{42}$ The Commentary to Article 22 of the MAC refers to the right to confidentiality and to the right to privacy including the various instruments addressing privacy with specific reference to the automatic processing of personal data (i.e. information relating to an identified or identifiable individual). ${ }^{43}$ The Commentary also states that when revising the Convention in 2010, it was decided to make it clear that the party receiving the information shall treat them in compliance not only with its own domestic law, but also with safeguards that may be required to ensure data protection under the domestic law of the supplying party. Such safeguards, as specified by the supplying party, may for example relate to individual access, independent oversight or redress.

- The CRS and the MCAA refer to the rules for confidentiality and other safeguards as provided for in the MAC. The MCAA contains an Annex D (Confidentiality Questionnaire) which can be also included by the parties when concluding the MCAA.

- At the level of the European Union, the 2011 Directive on Administrative Cooperation (DAC1) ${ }^{44}$ states in Article 16(1) the following: 'information communicated between Member States in any form pursuant to this Directive shall be covered by the obligation of official secrecy and enjoy the protection extended to similar information under that national law of the Member State which received it'. Thus, the protection of confidentiality is left to the domestic law of the recipient country. Furthermore, Article 25 of DAC1 stipulates that all information has to be exchanged in compliance with the Data Protection Directive (see below): 'Lhtowever, Member States shall, for the purpose of the correct application of this Directive, restrict the scope of the obligations and rights provided for in Article 10, Article 11(1), Articles 12 and 21 of the data protection directive) to the extent required in order to safeguard the interests referred to in Article 13(1)(e) of that Directive'.

The abovementioned examples show that even though in most of the instruments to exchange information the reference to confidentiality and privacy are made, these instruments do not provide any specific safeguards to protect the right to confidentiality and the right to privacy. These instruments have left the protection of taxpayers' rights to international conventions (e.g. Council of Europe Convention for the Protection of Individuals with Regard to Automatic Processing of Personal Data 1981 and its Additional Protocol of 8 November 2001.), ${ }^{45}$ the EU Data Protection Directive and to domestic legislation. ${ }^{46}$ However, there is not one multilateral instrument that provides for specific safeguards that countries need to provide when exchanging information in order to protect the right to confidentiality and the right to privacy.

The Council of Europe Convention mentioned above is the only binding instrument that potentially can have worldwide application since the 2001 Protocol opened this Convention to countries non-members of the Council of Europe. However, the scope of application is limited since up till the time of writing (March 2017), only three countries outside the Council of Europe i.e. Uruguay (in 2013); Mauritius and Senegal (in 2016) have ratified this Convention. ${ }^{47}$ Thus, even in this case, one can safely conclude that countries have not made use of this instrument to provide a multilateral framework that protects the automatic processing of personal data. ${ }^{48} \mathrm{Up}$ to the authors' best knowledge, no other (binding) Conventions exist to protect the right to confidentiality and the right to privacy.

Some non-binding instruments are for instance the 2006 OECD Manual on Information Exchange dealing with the general and legal aspects of EOI including confidentiality and tax secrecy (section 13). ${ }^{49}$ Other non-binding OECD instruments are the 1980 (updated in 2013) OECD Guidelines on the protection of Privacy

\section{Notes}

42 Art. 22 states that 'any information obtained by a Party under this Convention shall be treated as secret and protected in the same manner as information obtained under the domestic law of that Party and, to the extent needed to ensure the necessary level of protection of personal data, in accordance with the safeguards which may be specified by the supplying Party as required under its domestic law'.

43 Para. 216 Commentary to Art. 22(1). The instruments are for example the OECD Privacy Guidelines on the Protection of Privacy and Transborder Flows of Personal Data (1980 and updated in 2013); the Council of Europe Convention for the Protection of Individuals with regard to Automatic Processing of Personal Data of 28 Jan. 1981 and its additional Protocol of 8 Nov. 2001

44 Art. 16 remains the same in the DAC2 that contain the recent amendments to the 2011 Directive. The 2011 Directive was amended by extending the cooperation between tax authorities to automatic exchange of financial account information (Council Directive 2014/107/EU) and cross-border tax rulings and advance pricing arrangements (Council Directive of 8 Dec. 2015).

45 The OECD Model and the MAC refer to this Council of Europe Convention, but the UN Model does not (cfr. para. 5.2. Commentary to Art. 26 UN Model)

46 See s. 3.3.1 for proposed safeguards.

47 Up till the time of writing (Mar. 2017), only six countries have expressed their intention to ratify the Convention (i.e. Cabo Verde, Senegal, Morocco, Mauritius, Tunisia and Uruguay). In force in Uruguay, Mauritius and Senegal.

48 See for an analysis of this Convention Lee Bygrave, International Agreements to Protect Personal Data, in Global Privacy Protection. The First Generation 26-28 (James B. Rule \& Graham Greenleaf eds, Edward Elgar Publishing Ltd. 2008).

49 Manual on the Implementation of Exchange of Information Provisions for Tax Purposes. Approved by the OECD Committee on Fiscal Affairs on 23 Jan. 2006 
and Transborder Flows of Personal Data ${ }^{50}$ and the 2013 OECD Guide on the Protection of Confidentiality of Information Exchanged for Tax purposes. ${ }^{51}$ The 1980 Guidelines (with the 2013 update) contain the following principles: (1) collection limitation, (2) data quality principle, (3) purpose specification principle, (4) use limitation principle, (5) security safeguards principle, (6) openness principle, (7) individual participation principle, and (8) accountability principle. ${ }^{52}$ The 2013 OECD Guide on the Protection of Confidentiality provides best practices adopted by tax administrations to protect the tax confidentiality of the information exchanged. This 2013 OECD Guide also provides recommendations to help tax authorities to ensure that confidential taxpayer information is being adequately safeguarded.

Outside the OECD, other instruments include the UN 1990 Guidelines on Privacy and Data Protection ${ }^{53}$ These guidelines introduce some principles concerning the minimum guarantees that should be provided in national legislation. These principles are (1) lawfulness and fairness, (2) accuracy, (3) purpose-specification, (4) interested-person access, (5) non-discrimination, and (6) security. ${ }^{54}$ Some of these principles (security and purpose specification) are similar to those available in the OECD instruments (see above). A principle that is not available in OECD instruments, is the principle of accuracy that provides for 'the duty of data controllers to carry out regular checks of the quality of personal data'. This principle of accuracy can be useful in AEOI so that tax authorities are required to regularly check the accuracy of the data available for exchange. Another instrument that can provide inspiration to the regulation of privacy is the 2005 Asia-Pacific Economic Cooperation (APEC) Privacy Framework. ${ }^{55}$ This framework also provides for information privacy principles being (1) preventing harm, (2) providing notice, (3) collection limitations, (4) use of personal information, (5) mechanisms to exercise choice, (6) integrity of personal information, (7) security safeguards, (8) access and correction, (9) accountability. The framework is inspired on at that time OECD 1980 Guidelines on the Protection of Privacy and Transborder Flows of Personal Data (paragraph 5 preamble). ${ }^{56}$

Even though some of the instruments to exchange information mentioned above contain a provision ensuring the confidentiality of the information exchanged, the treatment of the information as confidential depends on the laws of the state requesting the information. For example, Article 26(2) OECD Model contains a specific reference to confidentiality. On the basis of this provision, the state which requests information is bound by a duty of confidentiality in respect of information which it obtains from the requested state. It has been submitted that this provision has direct effect, and the taxpayer who initially provided the information can thus enforce this obligation before the competent courts. ${ }^{57}$ The strength of this provision has however faded over time. In the 1963 OECD Model Convention, Article 26(1), in fine, contained an absolute duty of confidentiality: '(a)ny information so exchanged shall be treated as secret and shall not be disclosed to any persons or authorities other than those concerned with the assessment or collection of the taxes which are the subject of the Convention'. Currently, Article 26(1) only contains a relative duty of secrecy. This means that information should only be treated as secret in the same manner as information obtained under the domestic laws of the requesting state. This arguably does not constitute a sufficient safeguard anymore, as it depends on the laws of the state requesting the information.

Similarly, the MAC states that the protection of private data should be made in accordance to the domestic safeguards, which may be specified by the Supplying state. ${ }^{58}$ However, in the absence of safeguards by the Supplying state, the information may be exchanged without any restrictions with the state requesting the information.

In respect of the right to privacy, the provisions are even more scarce. The Commentary to Article 26 of the OECD and the UN Model refer to the rights and fundamental freedoms of the individual, including the right to privacy. ${ }^{59}$ However, the right to privacy is not specifically defined and it is embedded in the right to protection of personal data. There is no clarity on how this right to privacy is protected.

\section{Notes}

50 OECD, Recommendation of the Council Concerning Guidelines Governing the Protection of Privacy and Transborder Flows of Personal Data (23 September 1980) updated in 2013 (OECD Publishing 2013).

51 OECD, supra n. 4

52 Supra n. 50 ,

53 Guidelines concerning Computerized Personal Data Files. Resolution 45/95 of 14 Dec. 1990.

54 Ibid.

55 The content of the APEC Privacy Framework is available at http://www.apec.org/Groups/Committee-on-Trade-and-Investment/ /media/Files/Groups/ECSG/05_ecsg_ privacyframewk.ashx (accessed March 2017).

56 See for an analysis of this Framework, Bygrave, supra n. 48, at 43-45.

57 Diepvens \& Debelva, The Evolution of the Exchange of Information in Direct Tax Matters, supra n. 1, at 216

58 Art. 22(1) MAC Convention on Mutual Administrative Assistance in Tax Matters as Amended by the Protocol. OECD/Council of Europe, France (2011).

59 Para. 5.2 Commentary to Art. 26 UN Model. 
It is unsure what happens if the country does not have data protection laws or the data protection laws are obsolete ${ }^{60}$

Therefore, it is submitted that in the absence of an overarching international instrument, the problem of the protection of personal data and the right to privacy becomes more evident and urgent. The change from the standard of exchange on request to AEOI will require a binding instrument that can be ratified by countries agreeing to exchange information (i.e. countries that have signed the MAC and countries that have ratified the CRS and the MCAA). Since more than 100 jurisdictions have committed to EOI, the time is right to ask how to protect the confidentiality and privacy of the information exchanged.

At the level of the European Union, the new Directive on Administrative Cooperation (DAC2) strengthened the position of the taxpayer, by declaring that Reporting Financial Institutions and the competent authorities of each Member State shall be considered to be data controllers for the purposes of Directive 95/46/EC. ${ }^{61}$ This means that that the personal data needs to be:

- processed fairly and lawfully;

- collected for specified, explicit and legitimate purposes and not further processed in a way incompatible with those purposes;

- adequate, relevant and not excessive in relation to the purposes for which they are collected and/or further processed;

- accurate and, where necessary, kept up to date; every reasonable step must be taken to ensure that data which are inaccurate or incomplete, having regard to the purposes for which they were collected or for which they are further processed, are erased or rectified;

- kept in a form which permits identification of data subjects for no longer than is necessary for the purposes for which the data were collected or for which they are further processed.

Furthermore, information processed in accordance with the Directive shall be retained for no longer than necessary to achieve the purposes of the Directive, and in any case in accordance with each data controller's domestic rules on statute of limitations. ${ }^{62}$ Lastly, Member States shall ensure that each individual Reportable Person is notified of a breach of security with regard to his data when that breach is likely to adversely affect the protection of his personal data or privacy. ${ }^{63}$ These changes were probably inspired by comments of the Article 29 Working Party, who previously expressed its concerns relating to AEOI and data protection. ${ }^{64}$ The Working Party referred i. a. to the Digital Rights Ireland case (see infra). The authors concur with Somare and Wöhrer who submit that it will be hard to reconcile the position taken in the Directive with strict approach taken by the Court in the aforementioned case. ${ }^{65}$

\section{I.3.2 Recent EOI Initiatives and Pilot Projects}

At the time of writing, the OECD Global Forum on EOI has appointed a panel of experts from member jurisdictions to conduct a confidentiality and data safeguard preassessments on all jurisdictions committed to AEOI. According to the OECD, this review aims to ascertain the readiness of jurisdictions to receive data. ${ }^{66}$ This review should have been finalized by the end of 2016; however, at the time of writing (March 2017) it review is not yet available. Since countries have committed to the standard of AEOI by 2017 (early adopters) or 2018 (late adopters), it is urgent to have this review as soon as possible to give opportunity to countries to implement measures to protect the confidentiality and the protection of personal data that will be exchanged.

In order to make developing countries ready to implement AEOI, the OECD has also introduced two initiatives. One is the African initiative. The aim of this initiative is to engage with African countries which are members of the Global Transparency Forum on tax transparency and EOI. The objectives were to enhance participation of African countries, to ensure that African tax administrations have the ability and the tools needed to request, process and use information and to build EOI

\section{Notes}

60 Two examples are for instance Brazil that has not been able to enact a data protection law, and countries in Latin America and Africa that have enacted the data protection law but based on the 1995 Data Protection Directive. Since this Directive has now been repealed and new rules (Directive and Regulation) have been introduced to update the data protection laws to new developments, the question is how these countries will update their data protection laws, and if so, whether these countries will use the new rules in the EU. See s. 2.1.3.3. See also Mosquera et al., supra n. 5.

61 Furthermore, DAC2 states that each Member State shall ensure that each Reporting Financial Institution under its jurisdiction informs each individual Reportable Person concerned that the information relating to him will be collected and transferred and shall ensure that the Reporting Financial Institution provides to that individual all information that he is entitled to under its domestic legislation implementing Directive 95/46/EC in sufficient time for the individual to exercise his data protection rights.

62 Art. 1(5) Directive 2014/107/EU.

63 Art. 1(4) Directive 2014/107/EU.

64 Available at http://ec.europa.eu/justice/data-protection/article-29/documentation/other-document/files/2014/20140918_letter_on_oecd_common_reporting_standard.pdf. pdf (accessed March 2017).

65 See: Somare \& Wöhrer, supra n. 2, at 813. Similar concerns were expressed by the AEFI Group, which identified several shortcomings in the DAC2 Directive and submitted it might potentially infringe the principle of proportionality. See: https://ec.europa.eu/taxation_customs/sites/taxation/files/docs/body/first_report_expert_group_automatic exchange_financial_information.pdf (accessed March 2017).

66 See information available at the OECD AEOI portal. http://www.oecd.org/tax/automatic-exchange/commitment-and-monitoring-process/ (accessed March 2017). 
capacity within African regional organizations such as the African Tax Administration Forum. However, this initiative will come to an end by the end of $2017 .{ }^{67}$

Another recent development are the pilot projects which partner developed and developing countries to help developing countries to implement automatic exchange of financial account information developed by the CRS. According to the 2015 Pilot Project Outline:

\section{for a jurisdiction to effectively engage in AEOI on financial information, it must have in place, as a minimum, four essential components: (i) a legal basis for exchange; (ii) rules that require financial institutions to report information and follow due diligence procedures consistent with the Standard; (iii) administrative and IT infrastructure to collect and exchange information under the Standard and (iv) confiden- tiality and data safeguards. Each component is critical; there- fore all four must be in place. The extent and scale of assistance needed under each heading will vary from country to country depending on the extent to which these components (e.g. legislation, IT capacity, specialised staff) are already in place and the size and composition of the financial sector.}

However, the number of countries participating in this project are limited, and up till the time of writing (March 2017) only six pilot projects have been carried out. ${ }^{68}$ The authors applaud these recent initiatives, but it is currently too soon to assess their impact in practice.

\section{I.3.3 Autonomous Instruments}

\subsection{Taxpayers' Rights}

In the last decade, the rights and obligations of the taxpayer have received more attention by international organizations. For instance, the OECD has introduced instruments such as the 2003 Practice Note on Taxpayers' Rights and Obligations ${ }^{69}$ and the 2015 Report on Tax Administrations in OECD countries and other advanced and Emerging Economies. ${ }^{70}$ The 2015 Report on Tax Administrations has identified the following taxpayer's rights and obligations ${ }^{71}$ : (1) the right to be informed, assisted and heard, (2) the right of appeal, (3) the right to pay no more than the correct amount of tax, (4) the right to certainty, (5) the right to privacy and (6) the right to confidentiality and secrecy. These rights are usually accompanied by obligations such as the duty to be honest; to be co-operative; to provide accurate information and documents on time; to keep records; and to pay taxes on time. $^{72}$

Countries have also given attention to taxpayer rights and obligations. Examples include taxpayer charters and/or taxpayer declarations in Australia, Canada, Hong Kong and the United States. ${ }^{73}$ Furthermore, the Confédération Fiscale Européenne ${ }^{74}$ recently published a Model Taxpayer Charter in cooperation with the Society of Trust and Estate Practitioners (STEP) and the Asia-Oceania Tax Consultants' Association (AOTCA). ${ }^{75}$ However, in our view, one of the drawbacks of the OECD instruments and the charters of the various countries is that these instruments are not mandatory nor binding, and therefore it is up to the countries to apply them - or not. In some cases, these instruments merely serve as 'guidance' for tax authorities.

\subsection{Privacy and Data Protection Instruments}

The right to privacy is protected in International Conventions dealing with civil and political rights. For instance, the International Covenant on Civil and Political Rights addresses the right to privacy in Article $17(1){ }^{76}$ In addition, a non-binding instrument containing the right to privacy is the 1948 United Nations (UN) Declaration of Human Rights (Article 12). Some binding instruments at regional level that address the right to privacy are for instance the European Convention on Human Rights (Article 8), as ratified

\section{Notes}

67 African initiative: Engaging with African countries on tax transparency and EOI. https://www.oecd.org/tax/transparency/gf-african-initiative.pdf (accessed March 2017).

68 The pilot projects and partners are Albania-Italy; Colombia-Spain; Ghana-the United Kingdom; Morocco -France; Philippines -Australia; Pakistan- the United Kingdom. Furthermore, as stated in the 2017 Annual Report Global Forum on Transparency, three AEOI Implementation projects are underway with Saint Kitts and Nevis and Seychelles and a new project has been launched with Uruguay partnering with Mexico. 2016 Annual Report Global Forum on Transparency at 26.

69 OECD, Taxpayers Rights and Obligations (Paris: Centre for Tax Policy and Administration, OECD 2003).

70 These rights have been identified by the OECD in the Report on Tax Administrations in the OECD and other Advanced and Emerging Economies. The choice of countries for this report take into account OECD members, OECD accession countries, G20 countries that are non-OECD members and non-OECD members that are observers of the Committee of Fiscal Affairs, or whose revenue body has worked closely with the OECD over the recent years, and some countries to increase the geographical coverage (e.g. Morocco ad Thailand). See OECD, Tax Administration 2015: Comparative Information on OECD and Other Advanced and Emerging Economies 19 (Paris, OECD Publishing 2015).

71 Introduction to OECD, supra n. 69 and Ch. 9OECD, supra n. 70. These rights and obligations were identified by the OECD in the 1990 document entitled 'Taxpayers' rights and obligations - A survey of the legal situation in OECD countries. Document published by the OECD Committee of Fiscal Affairs Working Party Number 8.

72 OECD, supra $\mathrm{n} .70$, at 282-288. These rights have been also addressed in the OECD, Tax Administration 2013: Comparative Information on OECD and Other Advanced and Emerging Economics 276 (OECD Publishing 2013).

73 Pistone \& Baker, supra n. 1

74 The Confédération Fiscale Européenne is an umbrella organization that includes 26 national organizations from 21 European countries, representing more than 100,000 tax advisers.

75 The charter is available at http://www.cfe-eutax.org/node/3 (accessed March 2017).

76 Art. 17 (1) 'No one shall be subjected to arbitrary or unlawful interference with his privacy, family, home or correspondence, nor to unlawful attacks on his honour and reputation'. 
by European countries; and the Inter-American Convention on Human Rights (Article 11). ${ }^{77}$ However, if the country, which is a signatory to such a convention, hypothetically does not have domestic law to deal with the right to privacy or has not endorsed the international agreement, then, it could be reasonable argued that the individual will be left without protection. $^{78}$

Even if there are provisions applicable to the individual, these provisions often have a limited scope of application i.e. 'individuals' and 'protection of personal data'. The question will be what protection will be available if the affected taxpayer is a legal entity? Is the taxpayer also protected in case that the individual is acting as shareholder of a company?

Some countries actually do have domestic law dealing with privacy such as Privacy Acts (e.g. the United States, Canada) or Laws to regulate the protection of personal data (EU countries and some non-EU countries). However, one of the drawbacks is that these domestic provisions usually do not specifically address data protection in EOI for tax purposes. $^{79}$ Examples of personal information that will need to be protected are for instance, the taxpayer's address, the identity number, civil status, and biometric information.

Within the European Union, the most important instrument until recently was the old Data Protection Directive (1995), ${ }^{80}$ which is also in principle applicable to cross-border EOI. ${ }^{81}$ The 1995 Directive was repealed and replaced by a recently adopted ${ }^{82}$ new Data Protection Directive $^{83}$ and the General Data Protection Regulation. ${ }^{84}$
Most of the cases until now (see below) deal with the old Directive. On the basis of the Directive, Member States must inform the data subject (i.e. the taxpayer) if they disclose information which has not been obtained from the data subject himself. ${ }^{85}$ In principle, it should be possible for a taxpayer to deduce a right to be informed on the basis of this Directive. However, there are several exceptions to the obligations imposed by the Directive. First, Member States are not obliged to inform the data subject if he already is aware of the disclosure. ${ }^{86}$ Member States may also adopt legislative measures to restrict the scope of the rights contained in the Directive, if this restriction is deemed to be necessary to safeguard an important economic or financial interest of a Member State or of the European Union, including monetary, budgetary and taxation matters. ${ }^{87}$ The loss of tax revenue could thus constitute a reason for a Member State to restrict the rights contained within the Directive (see also above). ${ }^{88}$

Another problem arises in the case that non-EU countries have chosen to base their Laws on Data Protection on the principles of the 1995 EU Data Protection Directive. ${ }^{89}$ Due to the repeal of the 1995 EU Data Protection Directive, the question would be whether the Laws of non-EU countries will change to include the recently EU adopted changes. For instance, in respect of the new EU Data Protection Directive one may recommend to these non-EU countries to adopt from the new Directive the specific definitions of personal data, genetic data and biometric data (Article 3$)^{90}$ and the protection of the processing of

\section{Notes}

77 The text of the Inter-American Convention including Art. 11 is available at: http://www.cidh.org/Basicos/English/Basic3.American Convention.htm (accessed March 2017)

78 Or it would take the victim of the breach an unreasonable amount of time to receive protection. e.g. the ECtHR will only rule on breaches of the ECHR after the prior exhaustion of domestic remedies.

79 Some even provide a carve-out for taxation, see infra.

80 Directive 95/46/EC on the protection of individuals with regard to the processing of personal data and on the free movement of such data ('Data Protection Directive').

81 ECJ, 16 Dec. 2008, C-73/07, Tietosuojavaltuutettu v. Satakunnan Markkinapörssi Oy and Satamedia Oy, \$37; T. Schenk-Geers, International Exchange of Information and the Protection of Taxpayers 252-253 (Kluwer Law International 2009); A. Brodzka, The Road to FATCA in the European Union, ET No. 10, $517-518$ (2013).

82 On 8 Apr. 2016 the Council adopted the Regulation and the Directive. And on 14 Apr. 2016 the Regulation and the Directive were adopted by the European Parliament. On 4 May 2016, the official texts of the Regulation and the Directive have been published in the EU Official Journal in all the official languages. While the Regulation will enter into force on 24 May 2016, it shall apply from 25 May 2018. The Directive enters into force on 5 May 2016 and EU Member States have to transpose it into their national law by 6 May 2018.

83 Directive (EU) 2016/680 of the European Parliament and of the Council of 27 Apr. 2016 on the protection of natural persons with regard to the processing of personal data by competent authorities for the purposes of the prevention, investigation, detection or prosecution of criminal offences or the execution of criminal penalties, and on the free movement of such data.

84 Regulation (EU) 2016/679 of the European Parliament and of the Council of 27 Apr. 2016 on the protection of natural persons with regard to the processing of personal data and on the free movement of such data, and repealing Directive 95/46/EC (General Data Protection Regulation).

85 Art. 11 Data Protection Directive.

86 Art. 11(1) Data Protection Directive.

87 Art. 13(1) e) Data Protection Directive.

88 See also, A. Rust, Data Protection as a Fundamental Right, in Exchange of Information and Bank Secrecy 191 (A. Rust \& E. Fort eds, Kluwer Law International 2012).

89 A comparative analysis of the Laws or (Draft Bills) on Data protection to regulate the protection of personal data of Brazil, Colombia, South Africa and Uruguay demonstrated that these Laws or Draft Bill (Brazil) are to a large extent based on the 1995 Data Protection Directive. For instance, in respect of the conditions for lawful processing of data and the transfer of personal data to third countries. An analysis of the domestic provisions of these countries dealing with the right to privacy and the right to confidentiality has been presented at the June 2016 Conference: A Sustainable Path for Tax Transparency in Developing Countries https://www.jus.uio.no/ior/english/research/projects/global-tax-tranparency/events/conferences/a-sustainable-path-for-tax-transparency-in-develop.html (accessed March 2017). A forthcoming article addressing the main findings of this research will be published in 2017. See Mosquera et al., supra n. 5.

90 For this purpose, the definitions used in the revisited Data Protection Directive may be used. In Art. 3 of the Directive, the following definitions are provided:

(1) personal data' means any information relating to an identified or identifiable natural person ('data subject'); an identifiable natural person is one who can be identified, directly or indirectly, in particular by reference to an identifier such as a name, an identification number, location data, an online identifier or to 
these data as special categories of personal (sensitive) data (Article 10).

\section{I.3.4 Case Law}

Several (regional) courts have also read specific safeguards into more general norms providing the right to privacy. also been added by the respective regional courts. One of the first cases which came to the authors' attention is F.S. v. Germany, a case before the European Commission of Human Rights. ${ }^{91}$ The taxpayer in this case claimed that the information exchange on the basis of the old mutual assistance directive (77/799/EC) was contrary to its right to privacy as enshrined in Article 8 ECHR ('Right to respect for private and family life'). The Commission dismissed this claim, by stating that the EOI was indeed an interference with Article 8 ECHR, but this interference was justified as it was: (1) in accordance with the law, (2) taken in the interest of the economic well-being of the country, and also aimed at the prevention of crime, and (3) was necessary in a democratic society to achieve that aim. A similar approach was followed in the recent Othyma Investments $B V$ v. Netherlands ${ }^{92}$ and G.S.B. v. Switzerland case (2015). ${ }^{93}$ As Baker, in our view, rightfully submitted, if information is obtained in accordance with Article 8 ECHR prior to the exchange thereof, it is hard to imagine that the exchange of this information will be in breach of that article. ${ }^{94}$ This however presupposes that the information was actually rightfully collected. In addition, questions can arise regarding the use and storage of the information after it has been transferred to another jurisdiction (see below).
Recently, at the level of the European Union, the European Court of Justice has also pronounced itself on several cases involving the right to data protection. For tax in particular the following cases are of importance. In Satamedia, ${ }^{95}$ the CJEU confirmed that the collection and transfer of data relating to the earned and unearned income and assets of natural persons can be regarded as the processing of personal data of the 1995 Directive (supra). ${ }^{96}$ Later on, the Court ruled in Digital Rights Ireland that the need for safeguards in relation to data is even greater where personal data are subjected to automatic processing and where there is a significant risk of unlawful access to those data. ${ }^{97}$ In the even more recent (1 October 2015) Bara case, the Court specified that tax data should be considered as personal data and should thus fall within the scope of the Data Protection Directive. ${ }^{98}$ A few days later $(6$ October 2015), the Court, in Schrems, again emphasized the need for an effective protection. ${ }^{99}$ On the basis of these cases, one can reluctantly conclude that the CJEU is increasingly taking notice of the right to privacy.

However, one must keep in mind that the approach of the ECJ evidently stays casuistic and might even turn out negative for the taxpayer. An example is the Sabou case where the Court had to rule on taxpayer protection in the framework of the old mutual assistance directive. In short, the Sabou ${ }^{100}$ case concerned a tax assessment issued by the Czech tax authorities based on information obtained from other Member States. Sabou claimed that the tax authorities had illegally obtained information about him, as he was not informed of the requests for assistance (and thus not involved in formulating the questions); and because he was also not invited to take

\section{Notes}

one or more factors specific to the physical, physiological, genetic, mental, economic, cultural or social identity of that natural person;

(2) genetic data' means personal data, relating to the inherited or acquired genetic characteristics of a natural person which give unique information about the physiology or the health of that natural person and which result, in particular, from an analysis of a biological sample from the natural person in question,

(3) biometric data' means personal data resulting from specific technical processing relating to the physical, physiological or behavioural characteristics of a natural person, which allow or confirm the unique identification of that natural person, such as facial images or dactyloscopic data.Art. 3 Directive (EU) 2016 680 of the European Parliament and of the Council of 27 Apr. 2016 on the protection of natural persons with regard to the processing of personal data by competent authorities for the purposes of the prevention, investigation, detection or prosecution of criminal offences or the execution of criminal penalties, and on the free movement of such data, and repealing Council Framework Decision 2008/977/JHA.

91 European Commission of Human Rights, 27 Nov. 1996, F.S. v. Germany (Application No. 30128/96).

92 European Court of Human Rights, 16 June 2015, Otbyma Investments BV v. the Netherlands (Application No. 75292/10).

93 European Court of Human Rights, 22 Dec. 2015, G.S.B. v. Switzerland (Application No. 28601/11).

94 P. Baker, Double Taxation Conventions and Human Rights, in Tax Polymath: A Life in International Taxation 64-65 \& 69-71 (P. Baker \& C. Bobbett eds, IBFD 2010).

95 ECJ, supra n. $81, \S 37$.

96 Satamedia also appealed to the ECHR following the ECJ decision stating that the decision to prohibit the processing of personal data was (1) contrary to Art. 10 of the ECHR (i.e. freedom of expression) and (2) the length of the proceedings was against Art. 6 (right to a fair trial). The ECHR in decision of 21 July 2015 made its own analysis of Art. 10 and concluded that the freedom of expression was not violated. The Court referred to the analysis made by the ECJ and the domestic courts. The Court concluded that the restrictions to the freedom of expression were necessary in a democratic society and that the domestic courts struck a fair balance between the competing interest at stake (i.e. freedom of expression vs. right to privacy). In respect of Art. 6, the Court concluded that the length of the proceedings was in breach with the right to fair trial. For this breach, the amount of EUR 9500 was granted to the applicants. See ECtHR, 21 July 2015, Satakunnan and Satamedia v. Finland. European Court of Human Rights (Application no. 931/13).

97 ECJ, 8 Apr. 2014, C-293/12 and C-594/12, Digital Rights Ireland Ltd, \$55.

98 ECJ, 1 Oct. 2015, C-201/14, Smaranda Bara, §23.

99 ECJ, 6 Oct. 2015, C-362/14, Maximillian Schrems, \$42.

100 ECJ, 22 Oct. 2013, C-276/12, Sabou. 
part in the examination of witnesses. According to the Court, the involvement of the taxpayer was not required, as these procedures merely took place in the investigation stage (i.e. information collecting), which must be distinguished from the contentious stage. The outcome of this case has been heavily criticized, ${ }^{101}$ particularly because of the artificial division the court made between both stages. ${ }^{102}$ This demonstrates that a casuistic approach is not always beneficial for the taxpayer nor will it necessarily result in the development of a coherent overarching framework of protection. We submit that developing a (legislative) framework will enhance the taxpayer protection in this field in a faster, more uniform and coherent manner.

\subsection{Some Practical Issues}

\subsection{Disclosure of Information}

Information can be requested for various reasons and be disclosed after the exchange has taken place for several purposes.

Article 26 (2) OECD Model states that the information shall be disclosed 'only to persons or authorities (including courts and administrative bodies) concerned with the assessment or collection of, the enforcement or prosecution in respect of, the determination of appeals in relation to the taxes referred to in paragraph 1, or the oversight of the above'. Furthermore, in 2012 a final paragraph to Article 26(2) made it possible for the tax administration of the supplying state to exchange information with the receiving State not only for tax purposes but also for non-tax purposes (e.g. combatting corruption, anti-money laundering). ${ }^{103}$

In general, the EOI with supervisory and administrative bodies and the use of information for non-tax purposes has been widely accepted by countries in their tax treaties or TIEAs. ${ }^{104}$ However, it is not clear from these instruments how these supervisory and administrative bodies should be identified. ${ }^{105}$ Therefore, the domestic law will be applicable to determine the nature of supervisory or administrative body. The lack of clarification may also have consequences in the administrative and/or criminal sanctions that may be applicable in case of breach of confidentiality by these bodies.

The improper disclosure may also lead to confidentiality issues in case of stolen or illegal obtained information, or when information is shared with other countries in the absence of an EOI agreement or proper safeguards to protect the confidentiality of the information. The question that should be asked is whether the confidentiality may also apply to the use by the tax administration of illegally obtained (i.e. stolen) information. ${ }^{106}$ In the KB-Lux case, ${ }^{107}$ the Belgian tax administration spontaneously forwarded information on financial accounts held in the names of Dutch residents at Kredietbank Luxembourg (KB-Lux) to the Dutch tax administration. This information was stolen by five KB-Lux employees and spontaneously given to the Belgium tax authorities. In Belgium, since this information has been obtained illegally it was (at least at that time) not possible to use 'tainted' evidence. ${ }^{108}$ In contrast, in the Netherlands, the use of this information by the tax administration was authorized by Dutch Courts. ${ }^{109}$

\section{Notes}

101 CFE ECJ Task Force, Opinion Statement ECJ-TF 2/2014 of the CFE on the Decision of the European Court of Justice in Sabou (Case C-276/12), Concerning Taxpayer Rights in Respect of Exchange of Information upon Request, 7 Eur. Tax'n 318-321 (2014)

102 Diepvens \& Debelva, The Evolution of the Exchange of Information in Direct Tax Matters, supra n. 1, at 217-218.

103 Art. 26(2) states 'Any information received under paragraph 1 by a Contracting State shall be treated as secret in the same manner as information obtained under the domestic laws of that State and shall be disclosed only to persons or authorities (including courts and administrative bodies) concerned with the assessment or collection of the enforcement or prosecution in respect of, the determination of appeals in relation to the taxes referred to in paragraph 1, or the oversight of the above. Such persons or authorities shall use the information only for such purposes. They may disclose the information in public court proceedings or in judicial decisions. 'Notwithstanding the foregoing, information received by a Contracting State may be used for other purposes when such information may be used for such other purposes under the laws of both States and the competent authority of the supplying State authorises such use'. The last paragraph in Italics was added in the update of 17 July 2012. As stated in the OECD Commentary (para. 12.3), the aim if this new paragraph is 'to allow the sharing of tax information by tax authorities with other law enforcement agencies and judicial authorities on certain high priority matters (e.g. to combat money laundering, corruption, terrorism financing)

104 For illustration purposes, the TIEA concluded by Colombia and the United States allows the exchange of information for money laundering and other criminal purposes. Art 4(8) of the TIEA concluded by Colombia with the United States in 2001 (in force Apr. 2014) includes in addition to the text of Art. 8 the TIEA, an additional text (emphasis added): 'Any information received by a Contracting State shall be treated as secret in the same manner as information obtained under the domestic laws of that State and shall be disclosed only to persons or authorities of the applicant State, including judicial and administrative bodies involved in the determination, assessment, collection, and administration of taxes under this Agreement, the recovery of fiscal claims derived from such taxes, the enforcement of the tax laws, the prosecution of fiscal violations or the determination of administrative appeals in relation to such taxes, and the oversight of the above. Such persons or authorities may use the information only for such purposes and may disclose it in public court proceedings or in judicial decisions of the applicant State in relation to such matters'.

105 In this argument see also M.B.A. van Hout, Gedeeld geheim, verloren geheim, Tijdschrift Formeel Belastingrecht (2015/6). Van Hout rightly states that the confidentiality provisions in tax law are overruled by almost uncountable legal provisions that require that tax authorities provide information of taxpayers to other mainly governmental entities. Furthermore, taxpayers are mostly not informed if the tax authorities are required to provide information to others.

106 From a perspective of exchange of information, the use of stolen information by countries has been addressed in s. 4.4. of the IFA General Report. See Oberson, supra n. 1.

107 Other examples include the 'Falciani-list'. See on the use of leaked and stolen information by tax authorities, M. Dirkis, The 'Lion's Mouth' Postbox: A Comparative Review of the Limitations on the Use by Revenue Authorities of Leaked and Stolen Information, a paper presented to the Sydney - Max Planck Institute Tax Research Conference, University of Sydney, 28 Nov. 2016

108 H. Dubois \& D. Herbosch. De KB Lux-klanten gevonnist. Tijdschrift voor fiscaal recht 900-910 (Brussel 2006), no. 311.

109 The KB-lux case has decided in several cases by the Dutch courts. See for an overview on the cases http://www.futd.nl/dossiers/dossier-zwartspaarders/special-kb-lux-dossier/ (accessed March 2017). (In Dutch).Several articles have been also published in the KB-Lux case. See for instance on the use of (illegally obtained evidence), Sjobbema, G.H.Het duivelse dilemma 
A more recent case is for instance the use of information obtained in the so called 'Panama Papers'. The information obtained by the International Consortium of Investigative Journalists was made available to the public by means of news reports and a searchable database. ${ }^{110}$ The illegally obtained information ${ }^{111}$ has been also spontaneously exchanged with other tax administrations regardless of whether there are proper safeguards for confidentiality in the other country and of whether there is an EOI agreement. It appears that the diverging national practices regarding the use of illegally obtained information lead to the unsatisfactory result that the protection of the taxpayer potentially depends on the nationally developed constitutional safeguards. It is clear that adopting a fragmented approach is detrimental, in particular for internationally mobile taxpayers (see also infra, section 3).

\subsubsection{Trade (and Business) Secrets}

Most instruments also provide an exception to the obligation to provide information in case the requested information might qualify as a 'trade secret'.

Both the OECD Model and the OECD Commentary do not provide a definition of these terms. In the absence of a precise definition, these terms have to be construed in accordance with the domestic law of the treaty partners, by relying on Article 3(2) OECD Model. The OECD Commentary however warns for a too broad interpretation of the term 'secret', as this might render the EOI ineffective.112 The protection should strike a balance between the efficiency of the EOI procedure and the rights of the taxpayer. In doing so, the requested state should keep in mind that the information which is provided is also covered by the confidentiality requirements of Article 26(2). ${ }^{113}$

This ground for refusal applies to secrets of a certain commercial importance. ${ }^{114}$ In assessing this, three criteria were suggested by Vogel: (1) it concerns knowledge to which no more than a limited group of people have access, (2) the information is capable of being exploited economically, and (3) the disclosure of the information might place third parties at an advantage over those persons whose interests are protected by the secret. ${ }^{115} \mathrm{~A}$ similar description can be found in the OECD Commentary: 'facts and circumstances that are of considerable economic importance and that can be exploited practically and the unauthorised use of which may lead to serious damage (e.g. may lead to severe financial hardship)'. ${ }^{116}$ Therefore, as rightly stated by Ring when analysing the interpretation of the wording of the OECD Commentary to Article 26(3):

a state should not decline to disclose information simply because such disclosure might be embarrassing, produce bad publicity or increase taxes. Moreover, financial information cannot generally be considered a trade secret. Just as with the exception for privileged communications (and other similar information protected under domestic law), this exception permits a state to decline to provide information but does not require it to do so. Thus, a state may disclose 'secret' information if the requested state determines that subsequent disclosure (leaking) to the public or to competitors is unlikely, given the confidentiality provisions of the tax treaty. ${ }^{117}$

This means that the interpretation of trade secret and business secrets is very narrow but in some cases it is up to the Requested state to decide whether or not the information can be disclosed.

In general, financial information, including books and information, do not by its nature constitute such trade secrets, but in certain limited cases, the disclosure of such information might nevertheless reveal a trade, business or other secret. ${ }^{118}$ In the BJY case before the Singapore High Court, it was decided that banking documents did not fall within the narrow scope of the term 'business secrets'. ${ }^{119}$ The court rejected the argument of the taxpayer that the documents which were requested were similar to customer and supplier lists and therefore qualified as trade secrets.

Despite the fact that the Commentary warns for a too broad interpretation, a Dutch court has decided (in a similar case) that even a list of business contacts might

\section{Notes}

van de KB Lux-affaire: onrechtmatig bewijs of niet? Weekblad fiscaal recht vol. 137, 769-774 (Deventer 2008), no. 6773. See for an enforcement of tax law perspective, Aujke A.H. van Hoek \& Michiel J.J.P. Luchtman, Transnational Cooperation in Criminal Matters and the Safeguard of Human Rights, 1(2) Utrecht L. Rev. (Dec. 2005).

110 The searchable database on the Panama papers is available at https://panamapapers.icij.org/ (accessed March 2017).

111 It is not yet clear whether the information provided by the whistle-blower was stolen or obtained by hacking. http://www.independent.co.uk/news/world/politics/panamapapers-whistleblower-breaks-silence-to-explain-why-he-leaked-the-115m-files-a7017691.html (accessed March 2017).

112 Comm. Art. 26(3), §19.

113 Debelva \& Diepvens, Exchange of Information. An Analysis of the Scope of Article 26 OECD Model and Its Requirements. supra n. 1, at $305-306$.

114 DE: Bundesfinanzhof München 20 Feb. 1979, VII R 16/78; DE: Finanzgericht Düsseldorf, 20 Apr. 1982, discussed in X, Exchange of Information: Application of the BelgianGerman Tax treaty, 11 Euro. Tax'n 364-367 (1983).

115 K. Vogel, Double Taxation Conventions 1443, 110 (London, Kluwer Law International 1997).

116 Comm. Art. 26(3), §19.2.

117 See s. 2.3.4. D.M. Ring, Art. 26: Exchange of Information - Global Tax Treaty Commentaries, Global Tax Treaty Commentaries. IBFD.

118 Comm. Art. 26(3), §19.2.

119 SG: HC 13 Sept. 2013, Comptroller of Income Tax v. BJY and Others, [2013] SGHC 173. 
constitute a trade secret. ${ }^{120}$ The case concerned a request for information from the UK to the Dutch tax authorities regarding the shipment of Malibu-rum to a Dutch taxpayer. The taxpayer himself provided information to the Dutch tax authorities relating to the quantities of bottles he sold, including the identity of its clients. The taxpayer opposed the information exchange to the UK tax authorities on the ground that his activities consisted of the sale and resale of goods. If the producer of the goods would become aware of the taxpayer's clients, the produced would be able to contract directly with those clients, resulting in economic damage. The Court followed that reasoning and qualified the list of business contacts as a commercial secret. The different outcome in this case can in our view be explained by the fact that maintaining business contacts formed the core of the taxpayer's activities, the reluctance of the court to exchange this information was thus understandable. ${ }^{121}$

In assessing whether the requested state should refuse to provide the information, it should be considered whether the damage which is caused by exchanging the information can at a later stage still be mitigated or avoided. ${ }^{122}$ This clearly illustrates the importance of involving the taxpayer in this decision, as it are his or her economic interests which are at stake. Usually, it is also the taxpayer himself or herself who is in the best position to evaluate the nature of the information. In our view, it is advisable that (1) the requested state prior to refusing to exchange the information asks the requesting state how the information will be used and which procedures are in place to ensure the information will be treated confidentially, and (2) that the requested state indicates that the information contains secret information, as this might require special measures on the part of the requesting state to ensure its confidentiality. ${ }^{123}$

\subsubsection{Leak of Information to the Press and Third Parties}

In general terms, information may be exchanged if there is no reasonable basis for assuming that a taxpayer involved may suffer any adverse consequence due to the exchange. However, no further explanation is made in the instruments to exchange information to assess the existence of such a 'reasonable basis'; and therefore, the tax administration will play an important role in determining the consequences of the EOI for the taxpayer. The authors argue that even if there are provisions in the international EOI instruments to protect the right to confidentiality and the right to privacy, not all countries have these safeguards for instance because there is no treaty (the tax treaty and EOI treaty network is far from complete) or because there are no domestic rules in place.

Another issue which might arise is the fact that information might be leaked to third parties such as the press. The misuse of the TIE and the potential leaking of business data to the press may result in financial consequences for the taxpayer. This was analysed by the US Court of Appeals for the Ninth Circuit addressing Aloe Vera of America vs. the United States decided on 30th July 2009. ${ }^{124}$ In this case, Aloe Vera claimed civil damages due to the unauthorized disclosure in the Japanese news of the information exchanged under the provisions of the DTT between the United States and Japan. Aloe Vera claimed damages based on the duty of the tax administration in the United States to ensure that the confidentiality of the EOI should be protected. The US Court of Appeals, when analysing this case stated that it was not established whether the tax administration of the United States knowingly disclosed false information or knew that the foreign tax administration would misuse that information. For the US Court, negligence is not enough to rule against the US Government. One of the drawbacks of this decision is that the US Court of Appeals, the US Tax Administration and Aloe Vera focused on whether the statute of limitation of two years to claim damages by Aloe Vera had lapsed or not. Therefore, the Court only analysed the scope of the duty of confidentiality by the tax administration and the safeguards that the Receiving state (i.e. Japan) should have implemented to prevent the leak of information to the press very briefly.

Even if a compensation is awarded, it could be possible that the damages are limited taking into account the evaluation by the judge of the harm done by the disclosure and the lack of proof by the taxpayer of the economic damages. This was the conclusion of another later case initiated by Aloe Vera in the US District Court of Arizona and decided on 10th February 2015. ${ }^{125}$ Aloe Vera claimed civil damages due to the knowing disclosure of two cases of false information by the US Tax

\section{Notes}

120 NL: Court of Groningen 25 May 2004, No. 04/274. Note however that the case concerned the application of the old Mutual Assistance Directive (Directive 77/799/EEC)

121 Debelva \& Diepvens, Exchange of Information. An Analysis of the Scope of Article 26 OECD Model and Its Requirements, supra n. 1 , at 306.

122 OECD Committee on Fiscal Affairs, Tax Information Exchange Between OECD Member Countries, A Survey of Current Practices 30 (OECD 1994).

123 Ibid., at 31 .

124 Aloe Vera of America et al. v. United States, Case number 2:99-cv-01794 JAT, in the U.S. Court of Appeals for the Ninth Circuit http://cdn.ca9.uscourts.gov/datastore/ opinions/2012/11/15/10-17136.pdf (accessed March 2017).

125 Aloe Vera of America et al. v. United States, Case number No. CV-99-01794-PHX-JAT, in the U.S. District Court for the District of Arizona. http://www.dbriefsap.com/ bytes/AloeVeraCase.pdf (accessed March 2017). 
Administration to the Japanese Tax Administration. The Court estimated that in one of the cases, i.e. the unreported income statement, the United States knew this information to be false at the time of its disclosure. In the other complaint of disclosure, the proof provided by the taxpayer was not sufficient. In respect of the disclosure of the unreported income statement the Court decided that the tax administration acted negligent and that the disclosure of false return information was unauthorized by the tax treaty with Japan. Therefore, the Court awarded the plaintiffs USD 1,000 each in statutory damages. However, the claim by the plaintiffs amounted to USD 52 million. ${ }^{126}$ The judge declined to award the actual damages requested by the plaintiffs, on the basis that it was not demonstrated that they sustained that amount of economic harm as a direct result of the disclosure.

From a tax policy perspective, we argue that the taxpayers should also have access to domestic and international legal instruments and remedies to ensure that the confidentiality and the use of personal data are respected. ${ }^{127}$ These remedies should not be subject to too stringent domestic statutes of limitation. Furthermore, economic damages should also be granted in case of negligence of the tax administration, since the taxpayer could also suffer damage by the inaction of the tax administration.

\subsection{Evaluation}

The taxpayers' rights have been addressed in several instruments such as guidelines, taxpayer charters, and declarations. One of the drawbacks of these instruments is that they are not binding and, therefore, countries including tax administrations may in principle decide whether or not to apply the safeguards contained within these instruments. In the case of guidelines and charters, these instruments only serve as guidance for the tax administrations. The only binding instrument is the Council of Europe Convention for the Protection of Individuals with regard to Automatic Processing of Personal Data (1981) and its Additional Protocol of 8 November 2001 which could in principle be extended to countries outside the Council of Europe. However, outside the Council of Europe, this Convention has only been ratified by a limited amount of countries.
The bilateral and multilateral instruments to exchange information have introduced provisions addressing the protection of the right to confidentiality and to a smaller extent the right to privacy. The latter right has been mainly left to International Human Rights Conventions and to domestic legislation such as Privacy Acts and Laws.

The OECD and UN instruments also do not address the type of personal data that can be provided. In this context, it could safely be argued that all types of personal data can be exchanged such as date and place of birth, tax identification number, personal address, bank accounts, nationality, etc. The questions will be then, what is the legal basis to allow the exchange of personal data? What are the remedies available for the taxpayer if the personal data is leaked to the press or to third parties? Another relevant issue that should be taken into account is what happens if there is a mistaken identity and the personal data has been already exchanged?

These questions will be more relevant in AEOI since it will be more difficult and burdensome for the tax authorities to ensure the accuracy and protection of the information exchanged.

\section{A PROPOSED SOLUTION}

From the above, it is clear that the current protection of the taxpayer's rights is insufficient in this area. In this section, the authors will explore the possible adoption of a multilateral (binding) instrument for filling the lacunae in the existing legal framework. ${ }^{128}$ The need for such an instrument is currently greater than ever before, due to the adoption of AEOI as the global standard in the OECD, EU and US instruments described in section 2.1.2.

The reasons for the multilateral instrument are explained in section 3.1, the legitimacy in terms of participation and representation of countries and taxpayers in section 3.2 and the content of the BEPS multilateral instrument in section 3.3 .

\section{I Benefits of a Multilateral Instrument}

The instrument itself should be in a form of a binding Convention. The main benefits of a multilateral

\section{Notes}

126 The USD 52 million consisting of USD 47 million in economic damages resulting from the media reports and USD 5 million in attorneys' fees incurred to defeat the NTA assessments.

127 In our view, the main reasons for improving the position of the taxpayer and developing an overarching approach are the fact that different levels of protection apply based on the location of the taxpayer and different levels of protection is offered by different instruments. There is in our opinion a need for a uniform approach. It should also be recalled that possible obligations in respect of privacy and confidentiality arise from human rights instruments, which urges Member States to these instruments not only to refrain from infringing these rights, but they are also under positive obligations to ensure compliance with aforementioned rights. Lastly, the authors concur with the general idea that taxpayers rights should increase if the power of tax authorities increase, possible as a result of equity and fairness concerns. See ss 2.1.3. and 2.2. above.

128 Some authors have in the past already explored the possibilities for introducing multilateral tax treaties, see e.g. N. Mattsoon, Multilateral Tax Treaties - A Model for The Future?, 8-9(28) Intertax 301-308 (2000); M. Lang \& J. Schuch, Europe on Its Way to a Multilateral Tax Treaty, 1(9) EC Tax. Rev. 39-43 (2000); V. Thuronyi, International Tax Cooperation and a Multilateral Treaty, 4(26) Brook. J. Int'l L. 1641-1681 (2001); M. Pires, A Multilateral Tax Convention for the European Union?, 1(12) EC Tax Rev 43-44 (2003) 
instrument would be first that no bilateral instruments would need to be renegotiated, which would not only take a long while, but would lead to possible divergences between tax treaties that would be (re-)concluded. One would also not need to wait for changes to the OECD Model to trickle through to other Model Conventions such as the UN and TIEA Model Conventions.

Second, the multilateral instrument would also eliminate differences resulting from the application of regional standards (e.g. the guarantees provided by European Union Directives which are only applicable to EU Member States).

Third, the right to privacy and the right to confidentiality are guaranteed in several autonomous (human rights) instruments. By elaborating on the protection to be provided in the specific area of EOI, taxpayers would not need to wait several years for the protection to develop in the regional court's case-law, which would in turn enhance the legal certainty and legitimate expectations of the taxpayer. ${ }^{129}$

Fourth, the adoption of a multilateral treaty with a binding force does not render existing soft law instruments become obsolete, as in first instance they will serve as an inspiration for the rights to be included in the multilateral treaty, and, afterwards, they will be seen as complementing the multilateral treaty. However, the end result will be that the overall minimum level of protection will have increased.

Fifth, we acknowledge that other aspects of taxpayer protection are missing from the current EOI procedures (in particular, there is a lack of compliance with fair trial requirements), but we believe that the conclusion of a multilateral instrument solely for privacy and confidentiality would be easier for states than agreeing on a complete framework of protection in the short term. As mentioned in section 2.1, these two rights are definitely relevant, are currently underexposed and are interlinked.

Lastly, the adoption of uniform standards for privacy and confidentiality in an area where further protection is required could also incentivize the evolution and interpretation of such rights outside the area of EOI. This could result in the long run in the development of a true 'global standard'.
The major downside of adopting a multilateral instrument is that political consensus will need to be reached. This might be even harder when taxpayer rights are at stake in various jurisdictions. In the past, differences in legal systems have proven difficult to overcome when negotiating treaties, especially if this meant that states would have to provide safeguards where there were previously none. For example, the lack of agreement between states, mostly on the part of developing states, have halted the adoption of a widespread multilateral investment treaty. ${ }^{130}$ It cannot be excluded that similar issues would arise here However, the authors remain slightly hopeful in the light of the recent progress which was made in the light of the Multilateral Convention (see also below). ${ }^{131}$

\subsection{Legitimacy: Participation of Developed Countries, Developing Countries and Taxpayers in the Multilateral Instrument}

In order to enhance the legitimacy of the multilateral instrument, it has been argued by one of the authors elsewhere that multilateral instruments addressing EOI should take into account developing, developed countries and also involve the taxpayers. ${ }^{132}$ The definition of legitimacy has been addressed in respect of the OECD multilateral instruments to exchange information stating that 'input legitimacy will take into account the participation of all countries in the decision-making process and in the search of solutions on which the views of the OECD and non-OECD countries including developing countries are represented. Output legitimacy will take into account the problems of countries and citizens and the search for collective solutions to these problems'. ${ }^{133}$

In general, the argument of input legitimacy is based on the analysis of the instruments to exchange information which have been developed by the OECD following the G20 political mandate. Since developing countries are neither members of the OECD nor the G20, these instruments lack input legitimacy vis-à-vis developing countries. The reason for this is that

\section{Notes}

129 As mentioned supra, the CJEU recently ruled on several cases involving data protection. Even though some of the judgments are promising, such an approach remain casuistic.

130 According to the OECD: 'Negotiations on a proposed multilateral agreement on investment (MAI) were launched by governments at the Annual Meeting of the OECD Council at Ministerial level in May 1995. The objective was to provide a broad multilateral framework for international investment with high standards for the liberalisation of investment regimes and investment protection and with effective dispute settlement procedures, open to non-OECD countries. Negotiations were discontinued in April 1998 and will not be resumed'. http://www.oecd.org/investment/internationalinvestmentagreements/multilateralagreementoninvestment.htm (accessed March 2017).For the analysis of the contents of MAI and the reasoning for its failure see also S. Picciotto \& R. Mayne, Regulating International Business: Beyond Liberalization (MacMillan Press Ltd. Sept. 1999). See also Van Harten, Investment Treaty Arbitration and Public Law Oxford: Oxford University Press (2007).

131 A time efficient solution would be to include the abovementioned safeguard in the current BEPS Multilateral Convention, by way of amendment (Art. 33 Multilateral Convention). The drawback of this approach (which is arguably the most efficient way to implement these safeguards), is that only information exchanges between signatories to the BEPS Multilateral Convention would be covered.

132 Mosquera Valderrama, Legitimacy and the Making of International Tax Law., supra n. 1. at 358.

133 Ibid., ss 3.3 at 351 and 5.1.at 358 
developing countries have ratified the OECD multilateral instruments for EOI, but they have not participated nor have they been represented in the setting of the agenda and the drafting of the content of these instruments. ${ }^{134}$

Furthermore, these instruments also demonstrate a lack of output legitimacy. The main argument is that:

even though OECD and non-OECD (developing) countries have the same goals; the mechanisms to achieve these goals differ taking into account the differences in resources between developed and developing countries. It is this author's opinion that OECD countries may have a greater benefit from the instruments to exchange information. The main reason is that exchange of information may result in more revenue for countries that have the technological and administrative resources to deal with the information exchanged. $^{135}$

In respect of the taxpayer, the multilateral instruments to exchange information also lack input and output legitimacy vis-à-vis the taxpayer. The lack of input legitimacy is argued taking into account the lack of participation of the taxpayer in the decision making process of these instruments. Furthermore, the argument for the lack of output legitimacy is that the multilateral instruments to exchange information do not provide solutions to taxpayer's problems nor do the instruments protect taxpayers' rights. ${ }^{136}$

The Global Transparency Forum has resulted in the rights of taxpayer being repealed or reduced in order to comply with the recommendations of the peer review. The aim of the Forum is to exchange information swiftly (without delay) and effective. For illustration purposes, the IFA 2015 general report referred to the branch reports for Austria, Liechtenstein, the Netherlands, Portugal, Switzerland and Uruguay which stated that the procedure to notify the taxpayer including the possibility to challenge the EOI 'have been removed entirely or cut down'. In all cases, the removal of the right to notification and to challenge came about as a result of pressure from the OECD Forum on Transparency and EOI, and as a result of a threat to give a lower peer review rating to the countries concerned. ${ }^{137}$

Therefore, for this new multilateral instrument, the participation and representation of taxpayers, tax advisors and business representatives is deemed necessary. Taxpayers and tax advisors may also participate for instance by involving the World Taxpayers Association, the Confédération Fiscale Européenne, the International Fiscal Association consisting of tax advisors and academics among others. In addition, the participation of business representatives such as the International Chamber of Commerce and the Business and Industry Advisory Committee among others is also recommended. ${ }^{138}$ The following paragraph will deal with the safeguards of EOI to be included in the multilateral instrument.

\subsection{Content of the Multilateral Instrument}

\subsection{Safeguards in Exchange of Information}

In the past, Cockfield has rightly argued the risks for taxpayers' right to privacy due to the enhanced technology changes in TIE. This author rightly stated that:

to the extent that the technology change promotes heightened and ongoing sharing of taxpayer information, however, it also amplifies the risk that taxpayer rights such as privacy may be harmed. For this reason, governments need to ensure that reforms promoting effective TIE include efforts to encourage both efficient exchanges (i.e. exchanges that encourage low compliance costs for taxpayers and low administration and enforcement costs for tax authorities) and fair exchanges (i.e. exchanges that respect taxpayer rights such as privacy). Efficient and fair exchanges are discrete but related topics in the sense that both are necessary elements to accomplish effective TIE. If governments are not confident that their taxpayer information will be shared in a fair manner with foreign governments then they may be reluctant to exchange this information, harming efficient sharing. ${ }^{139}$

However, in the present authors' opinion it is the responsibility of the tax administrations to ensure that the EOI has sufficient safeguards to protect the confidentiality and privacy of the information exchanged. As rightly argued by Stewart 'national tax agencies make significant claims of expertise in administration and collection of data. They must be able to manage high level computing systems, and data storage and transmission systems, as well as legal and financial expertise to identify and utilize relevant data,. ${ }^{140}$

Nowadays, the technology is playing a more important role due to the introduction of AEOI as the

\section{Notes}

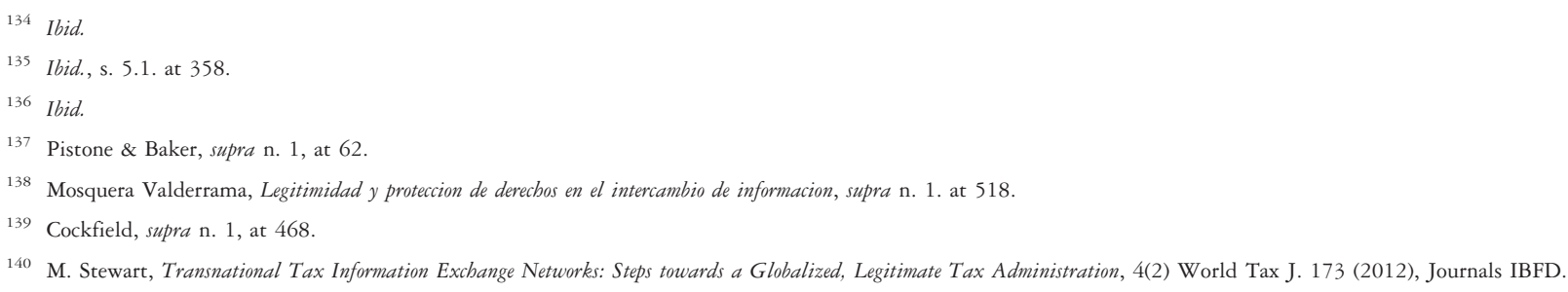


global standard. Therefore, the authors recommend the application of the principles of reciprocity, security safeguards, purpose specification, proportionality and accuracy in EOI including AEOI. These safeguards are necessary taking into account that the infrastructure to receive the information, to process the information, and to guarantee the confidentiality of tax information and personal data differ among countries.

The following safeguards were based upon international best practices and have been found in country's practices as well as in the 1980 (updated in 2013) OECD Guidelines on the protection of Privacy and Transborder Flows of Personal Data and the 2013 OECD report on the protection of confidentiality of information exchanged for tax purposes. ${ }^{141}$ Similar safeguards have also been mentioned in the guidelines on data protection which have been published by the Article 29 Working Party. ${ }^{142}$ In applying these principles, the EOI will result in sending of data by the supplying State if the following cumulative conditions are being met:

(1) similar data can be received from the receiving State (reciprocity) $^{143}$

(2) the receiving State ensures adequate protection of confidentiality and data privacy that is guaranteed by a follow up by the supplying State to guarantee the respect of such confidentiality in the receiving State (security safeguards) ${ }^{144}$;
(3) the exchange is adequate and relevant ${ }^{145}$ in relation to the purpose or purposes for which they are processed (purpose specification) ${ }^{146}$

(4) the sending of data does not constitute an excessive burden for the tax administration that lacks the administrative capacity or technical knowledge to develop a secure electronic system to exchange data (proportionality). This has been one of the concerns of the OECD projects to introduce AEOI when stating the need for developing countries to ensure that tax administrations have the ability and the tools needed to request, process and use information. $^{147}$

(5) the AEOI calls for the application of the principle of accuracy available in the UN 1990 Guidelines on Privacy and Data Protection (accuracy). ${ }^{148}$ By means of this principle the data controller has the duty to carry out regular checks of the quality of personal data. This principle is important in particular when dealing with bulks of information.

It is submitted that the conditions under which a country may suspend the EOI should be revised in order to ensure that all countries have safeguards to protect these rights and the administrative capacity and infrastructure to deal with the bulk of information that will be automatically exchanged. ${ }^{149}$ This information will be exchanged by using electronic systems ${ }^{150}$ that may differ between countries taking into account the administrative and technical capacity of developing and developed countries. ${ }^{151}$

\section{Notes}

141 OECD, supra n. 4.

142 Art. 29 Data Protection Working Party, Guidelines for Member States on the criteria to ensure compliance with data protection requirement in the context of the automatic exchange of personal data for tax purposes, WP 234, 16 Dec. 2015.

143 The IFA National reporters for Uruguay when addressing the principle of reciprocity stated that 'this principle implies that, upon receiving a request to exchange information, the requested state does not need to carry out administrative measures that are not permitted under the laws or practice of the requesting state or to supply items of information that cannot be obtained under the laws or practice of the requesting state. The rule also states that the requesting state cannot avail itself of the requested state's information system if it is wider than its own'. Uruguay National Report in Exchange of Information and cross-border cooperation between Tax Authorities (IFA Cahiers 2013), supra n. 1 at 820-821.

144 The purpose specification principle has been developed in the 2013 OECD Privacy Guidelines. Accordingly, 'the purposes for which personal data are collected should be specified not later than at the time of data collection and the subsequent use limited to the fulfilment of those purposes or such others as are not incompatible with those purposes and as are specified on each occasion of change of purpose'. At 14. In addition, the IFA General Reporters in 2015 identified the following as a best practice: '[a] requesting state should provide confirmation of confidentiality to the requested state'. See: Pistone \& Baker, supra n. 1, at 80

145 See on the interpretation of the necessity requirement in the context of interferences with the right to private life an data protection: European Data Protection Supervisor, Developing a 'toolkit' for assessing the necessity of measures that interfere with fundamental rights, 16 June 2016.

146 For instance, the IFA National Reporter Colombia addressed the principle of purpose limitation as provided by the Constitutional Court stating that 'a law enacted by the Congress which granted general, unrestricted powers to the tax authorities to request any type of information from the taxpayers was in violation of the Constitution. The Constitutional Court held that the tax information requested and disclosed must comply with the principle of purpose limitation (1) strictly necessary to fulfil the purposes of the tax administration in that particular case, and (2) used only for the purposes authorized by law. Constitutional Court Judgment C-1147 of 2001. Colombia, National Report in Exchange of Information and cross-border cooperation between Tax Authorities (IFA Cahiers 2013), supra n. 1, at $218-219$.

147 See African initiative and pilot projects s. 2.1.3.2. above.

148 Guidelines concerning Computerized Personal Data Files. Resolution $45 / 95$ of 14 Dec. 1990. See s. 2.1.3.1. above.

149 For instance the Commentary to s. 5 of the CAA refers to the OECD Confidentiality Guide and states that 'the ability to protect the confidentiality of tax information is also the result of a "culture of care" within a tax administration which includes the entire spectrum of systems, procedures and processes to ensure that the legal framework is respected in practice and information security and integrity is also maintained in the handling of information. As the sophistication of a tax administration increases, the confidentiality processes and practices must keep pace to ensure that information exchanged remains confidential'. CRS Full Version containing the Commentary to s. 5 of the CAA para. 1 at 79.

150 Examples of these electronic systems are for instance the Common Communication Network, TLW Mail Systems, Electronic Forms, Encrypted CD's and Track and Trace Emails. See Oberson, supra n. 1, at 37-38.

151 The differences in countries technical and administrative capacity including the use of secure electronic systems to exchange information has been addressed in the OECD Declaration on Automatic Exchange of Information in Tax Matters. Adopted on 6 May 2014 at 3. 
Countries that participate in the AEOI include both developed and developing countries. Therefore, the adoption of instruments by these countries may bring problems regarding the implementation of AEOI and the safeguards to protect such information. Developing countries do not have the financial resources, administrative capacity and technological equipment to process the information and to guarantee that the information will be secured and protected. Therefore, the Supplying state and the taxpayer should have the right to intervene and to object in case that the Receiving state does not have the resources to guarantee the confidentiality of the taxpayer's information. The OECD Multilateral instruments, for example, make the suspension possible of the EOI by one of the countries in cases of non-compliance with confidentiality and data safeguard provisions as stated in the OECD Model and in the Competent Authority Agreement implementing the CRS. Even if the Supplying country has safeguards to protect the confidentiality of the EOI it is very difficult to ensure that the other country (Receiving country) will have the same level of protection. The shortcomings of developing countries have been partially addressed by the OECD by introducing the African initiative and the pilot projects between developed and developing countries (section 2.1.3.2. above).

However, as we have addressed in sections 2.1. and 2.2. above, in our view there are still many shortcomings in the protection of privacy and confidentiality in EOI. Therefore, as rightly stated by Bentley in respect of the rise of soft law but also applicable to the developments in the rules to exchange information 'revenue administrators have been placed in a position where they have to engage with and understand taxpayers as much as they can. To do this effectively they have to protect taxpayers and set up the frameworks that provide effective rule of law both under the law and through the daily operational administration of the law'. ${ }^{152}$ This means that in respect of EOI, and as part of the rule of law, the taxpayers need to trust that the tax administration will protect their rights to confidentiality and to privacy. Thus, in our view, the time is right to develop a multilateral instrument to remedy the shortcomings in the existing safeguards to protect these rights.

\section{Conclusion}

The increasing flows of information between countries undoubtedly provides advantages in terms of increased compliance and increased revenue. The increased availability of information also presents some challenges with regard to the protection of the taxpayer's rights. The right to privacy and confidentiality, have not yet gained sufficient attention in this debate. The authors conclude that the existing safeguards in this respect are not sufficient to tackle the existing issues. The conclusion of a specific multilateral instrument could remedy some shortcomings. In this respect, the authors propose the implementation of the following safeguards: (1) similar data can be received from the receiving State (reciprocity), (2) the receiving State ensures adequate protection of confidentiality and data privacy that is guaranteed by a follow up by the supplying State to guarantee the respect of such confidentiality in the receiving State, (3) the exchange is adequate, relevant and not excessive in relation to the purpose or purposes for which they are processed, (4) the sending of data does not constitute an excessive burden for the tax administration that lacks of the administrative capacity or technical knowledge to develop a secure electronic system to exchange data, and (5) the principle of accuracy, stipulating that the data controller has the duty to carry out regular checks of the quality of personal data

A previous draft of this article was presented at the Fourth Annual Tax Symposium, organized by the University of Washington School of Law. The authors would like to thank the participants of the aforementioned conference and the anonymous peer reviewers of this article for their insightful comments and suggestions.

\section{Notes}

152 D. Bentley, The Rise of 'Soft Law' in Tax Administration-Good News for Taxpayers? Asia-Pac. Tax Bull. 38 (Jan./Feb. 2008), IBFD, Amsterdam. vol. 14 